\title{
Silver-reduced Graphene Oxide Composites prepared by spin coating technique as Cathode Material for Dye-Sensitized Solar Cells
}

\author{
M.Y.A. Rahman ${ }^{*}$, N. Mustaffa \\ Institute of Microengineering and Nanoelectronics (IMEN), Universiti Kebangsaan Malaysia, 43600, \\ Bangi, Selangor, Malaysia \\ *E-mail: mohd.yusri@ukm.edu.my
}

doi: $10.20964 / 2021.06 .36$

Received: 14 January 2021 / Accepted: 4 March 2021 / Published: 30 April 2021

Silver-reduced graphene oxide (Ag-rGO) composite films have been prepared via layer-by-layer spin coating method. The Ag-rGO samples were then employed as cathode in a dye-sensitized solar cell (DSSC). The main aim of this work is to study the relationship between spin coating cycle of Ag-rGO with the performance parameters of the device. Various spin coating cycles have been chosen, namely, 3,4,5,6 and 7 times. The highest transmittance of the sample is $7.5 \%$ corresponding with 3 spin-coating cycles. The highest $\eta$ of $0.840 \%, J_{\text {sc }}$ of $4.404 \mathrm{~mA} \mathrm{~cm}^{-2}$ and $F F$ of 0.329 were obtained from the device with 4 spin-coating cycles. This is due to this device has the smallest charge transfer resistance at the interface of $\mathrm{Ag}$-rGO/electrolyte $\left(R_{\mathrm{ct} 1}\right)$ of $14.37 \Omega$.

Keywords: cathode; dye-sensitized solar cells; reduced graphene oxide; silver

\section{$\underline{\text { FULL TEXT }}$}

(C) 2021 The Authors. Published by ESG (www.electrochemsci.org). This article is an open access article distributed under the terms and conditions of the Creative Commons Attribution license (http://creativecommons.org/licenses/by/4.0/). 